\title{
Cigarette smoke-induced DNA damage and repair detected by the comet assay in HPV-transformed cervical cells
}

\author{
AFSOON MOKTAR ${ }^{1}$, SRIVANI RAVOORI ${ }^{2}$, MANICKA V. VADHANAM ${ }^{2}$, \\ C. GARY GAIROLA ${ }^{3}$ and RAMESH C. GUPTA ${ }^{1,2}$ \\ ${ }^{1}$ Department of Pharmacology and Toxicology, ${ }^{2}$ James Graham Brown Cancer Center, University of Louisville, \\ Louisville, KY 40202; ${ }^{3}$ Graduate Center for Toxicology, University of Kentucky, Lexington, KY 40536, USA
}

Received April 1, 2009; Accepted June 4, 2009

DOI: 10.3892/ijo_00000447

\begin{abstract}
Human papillomavirus (HPV) is the causative factor in the development and progression of cervical cancers in $>97 \%$ of the cases, although insufficient. Epidemiological studies suggest an elevated risk of cervical cancer for cigarette smokers; therefore, we examined cigarette smoke-induced DNA damage and repair in HPV16-transformed human ectocervical cells (ECT1/E6 E7). Cells were treated with cigarette smoke condensate (CSC) for $72 \mathrm{~h}$ to assess the formation of single- and double-strand DNA breaks, measured by alkaline and neutral single cell gel electrophoresis assays, respectively. The mean tail length of cells with single-strand breaks was increased by $1.8-, 2.7$ - and 3.7 -fold $(\mathrm{p}<0.001)$ after treatment with 4,8 and $12 \mu \mathrm{g} / \mathrm{ml} \mathrm{CSC}$, respectively. The tail length with double-strand breaks was also increased dose-dependently. These results were further supported by measurement of the mean tail moment: the increase in both single- and double-strand breaks were much more pronounced with increasing concentration of CSC, by up to 23.5 -fold ( $\mathrm{p}<0.0001$ for both assays). To examine the DNA repair, cells were treated with CSC for $72 \mathrm{~h}$, followed by CSC withdrawal and re-incubation of the cells with fresh medium for 24, 48, or $72 \mathrm{~h}$. Both single- and double-strand DNA breaks were removed during the initial $24 \mathrm{~h}$ but no further removal of the damage was observed. Up to $80 \%$ of residual single- and double-strand DNA breaks $(\mathrm{p}<0.05)$ were found to persist at all CSC concentrations examined. Ellagic acid, a known antioxidant and free-radical scavenger, was found to significantly inhibit DNA breaks induced by CSC. Thus, free radicals may be a plausible source of CSCinduced DNA damage. These data show that CSC-mediated
\end{abstract}

Correspondence to: Dr Ramesh Gupta, Department of Pharmacology and Toxicology, University of Louisville, 304E Delia Baxter II, 580 S Preston St., Louisville, KY 40202, USA

E-mail: rcgupta@louisville.edu

Key words: cervical cancer, human papillomavirus, cigarette smoke condensate, comet assay, DNA strand breaks, ellagic acid
DNA strand breaks are highly persistent, and suggest that persistence of cigarette smoke-associated DNA damage in the presence of HPV infection may lead to increased mutations in cervical cells and ultimately higher cancer risk.

\section{Introduction}

Epidemiological and clinical data strongly support a major role by the human papillomavirus (HPV) in the etiology of cervical cancer (1-3). However, HPV alone appears to be insufficient for cervical cancer development as studies have shown that the majority of HPV infection is cleared by the immune response within 8-12 months (4). Further, additional cofactors were found to be required for prolonged expression of the HPV E6 and E7 oncogenes leading to development and progression of cervical abnormalities (5). One major risk factor in HPV-mediated cervical cancer is cigarette smoking, as it has been consistently linked with the progression of cervical neoplasia (6). Further, female smokers have two times higher risk of developing cervical cancer than nonsmokers (7).

Cigarette smoke-induced genotoxicity results in induction of micronuclei, sister chromatid exchange, chromosomal aberrations, microsatellite instability, DNA strand breaks and oxidative DNA damage $(8,9)$, Cigarette smoke is a heterogeneous mixture of approximately 5,000 chemical compounds, of which several dozens of them are carcinogens, co-carcinogens, mutagens and tumor promoters (10), including polycyclic aromatic hydrocarbons (PAH), N-nitrosamines, inorganic and organic compounds $(11,12)$.

Cigarette smoke has been shown to cause a variety of oxidative DNA damage, including the formation of 8-oxo7,8-dihydro-2-deoxyguanosine (8-oxoguanine) $(13,14)$. 8Oxoguanine is a common mutagenic DNA lesion which is formed abundantly by intracellular oxidation and exogenous carcinogens like cigarette smoke $(15,16)$. It has also been shown that cigarette smoke induces other forms of DNA damage, including single-strand breaks (SSBs) $(17,18)$ and possibly double-strand breaks (DSBs) $(19,20)$. In general, strand breaks result from the attack of a variety of endogenous and exogenous factors to the sugar residues of DNA (21). SSBs represent the initial DNA damage and are often used as a biomarker of exposure (22-24). DSBs are considered to be more biologically relevant since they can lead to chromosome 
translocation and cancer if repaired improperly in addition to genetic instability and cell death if left unrepaired (25). Cellular DNA repair capacity is of particular importance since it is a primary factor in how well a cell can overcome DNA insults by a genotoxic agent. An intact DNA repair system is crucial in order to combat the effects of various carcinogens which can induce DNA damage.

HPV-transfected cervical cells were chosen since it has been proposed that cigarette smoke has a late stage synergistic effect in the cervical carcinogenesis already initiated by HPV infection $(6,26)$. In order to study the role and possible mechanisms of cigarette smoke-induced DNA damage in the cells we employed single cell gel electrophoresis (SCGE), also known as the comet assay. It is a sensitive technique to detect DNA strand breaks as well as assess DNA repair kinetics at the single cell level $(24,27)$. We have employed comet assay $(28,29)$ to investigate: i) single- and double-strand DNA breaks following exposure of the HPV16-transformed human ectocervical cell line (ECT1/E6 E7) to cigarette smoke condensate (CSC); ii) the ability of the cells to repair CSCinduced DNA damage; and iii) the possibility of oxidative damage as the source of CSC-induced DNA strand breaks by employing ellagic acid (EA) as a known scavenger of reactive oxygen species $(30,31)$.

\section{Materials and methods}

Materials. Keratinocyte serum-free medium (K-SFM), bovine pituitary extract (BPE), epithelial growth factor (EGF), penicillin/streptomycin, trypsin/EDTA solution and low-melting agarose were from Invitrogen (Carlsbad, CA, USA); sodium N-lauroyl sarcosine, DMSO, Tris and spermine were from Sigma Aldrich (St. Louis, MO, USA); proteinase K was from Roche (Switzerland); EDTA was from Mallinckrodt Chemicals (Hazelwood, MO, USA); and ellagic acid was from LKT Laboratories (St. Paul, MN, USA).

Preparation of CSC. University of Kentucky research cigarettes (2R4F) were smoked in a Borgwardt 30-port smoking machine under standard FTC protocol (32). The particulates were collected on Cambridge filters and were dissolved in DMSO to obtain a $4 \%$ solution. The stock cigarette smoke condensate solutions were stored in small aliquots at $-80^{\circ} \mathrm{C}$. A fresh vial was used for each experiment.

DNA damage formation. HPV-16 transformed human ectocervical cells, ECT1/E6 E7, were a generous donation by Dr Raina Fichorova, Brigham and Women's Hospital, Harvard Medical School. The cells were routinely cultured as monolayer in K-SFM supplemented with $0.3 \%$ BPE, $0.1 \mathrm{ng} / \mathrm{ml}$ EGF, $0.4 \mathrm{mM} \mathrm{CaCl}_{2}, 1 \%$ penicillin and streptomycin at $37^{\circ} \mathrm{C}$ and $5 \% \mathrm{CO}_{2}$. Cells were seeded at a density of approximately 6,000 cells $/ \mathrm{cm}^{2}$ in $25 \mathrm{~cm}^{2}$ cell culture flasks. After cells reached $60-70 \%$ confluence, they were treated with either $0.2 \% \mathrm{v} / \mathrm{v}$ DMSO or with 4,8 and $12 \mu \mathrm{g} / \mathrm{ml} \mathrm{CSC} \mathrm{in} \mathrm{DMSO} \mathrm{for} \mathrm{up} \mathrm{to}$ $96 \mathrm{~h}$ in order to induce the maximum DNA strand breaks and then harvested by trypsin/EDTA solution. The cells were kept on ice at all times to minimize the DNA repair. All cell culture studies were performed independently three or four times.
DNA repair. ECT1/E6 E7 cells were treated with 4,8 or $12 \mu \mathrm{g} / \mathrm{ml} \mathrm{CSC}$ for $72 \mathrm{~h}$, followed by CSC withdrawal. Residual CSC was removed by washing the cells three times with $5 \mathrm{ml}$ medium, followed by incubation of the cells with the fresh medium for an additional 24,48 , or $72 \mathrm{~h}$ at $37^{\circ} \mathrm{C}$ to allow repair of DNA strand breaks to occur.

Ellagic acid treatment. ECT1/E6 E7 cells were pre-treated with EA ( 5 or $15 \mu \mathrm{M}, 0.2 \%$ DMSO) for $20 \mathrm{~h}$. Following this, medium was removed and fresh media containing CSC (4, 8 or $12 \mu \mathrm{g} / \mathrm{ml}, 0.2 \%$ DMSO) and EA (5 or $15 \mu \mathrm{M}, 0.2 \%$ DMSO) were added for $72 \mathrm{~h}$. Vehicle (0.2\% DMSO)-treated controls were analyzed in parallel.

Comet assay. DNA single- and double-strand breaks were detected by alkaline and neutral comet assays, respectively, as described (27,29). Briefly, 100,000 cells per slide were embedded in $1 \%$ low-melting agarose on frosted microscopic glass slides. The cells were subsequently lysed $(1.25 \mathrm{M}$ $\mathrm{NaCl}, 0.1 \%$ sodium $\mathrm{N}$-lauroyl sarcosine, $50 \mathrm{mM}$ Na-EDTA, $100 \mathrm{mM}$ Tris- $\mathrm{HCl}, \mathrm{pH} 10)$, digested with proteinase $\mathrm{K}$ (1.25 M $\mathrm{NaCl}, 5 \mathrm{mM}$ EDTA, $5 \mathrm{mM}$ Tris- $\mathrm{HCl}, 0.5 \mathrm{mg} / \mathrm{ml}$ proteinase $\mathrm{K}$, $\mathrm{pH} 10$ ) and DNA precipitated (50\% ethanol, $1 \mathrm{mg} / \mathrm{ml}$ spermine, 20 mM Tris-HCl, pH 7.4).

For single-strand breaks, the DNA was unwound by first soaking the slides in strong alkaline buffer $(0.6 \mathrm{mM} \mathrm{Na}$ EDTA, 0.18 $\mathrm{M} \mathrm{NaOH}, \mathrm{pH} 13)$ and then electrophoresed in the same buffer $\left(26 \mathrm{~V} ; 400 \mathrm{~mA}\right.$, at $\left.4^{\circ} \mathrm{C}\right)$. For double-strand breaks, the DNA was unwound using a neutralizing buffer (500 mM Na-EDTA, 0.2\% DMSO, $500 \mathrm{mM} \mathrm{NaCl}, 100 \mathrm{mM}$ Tris- $\mathrm{HCl}, \mathrm{pH} 9.0)$ and then electrophoresed in the same buffer $\left(26 \mathrm{~V} ; 250 \mathrm{~mA}\right.$ at $\left.4^{\circ} \mathrm{C}\right)$.

After staining the cells with ethidium bromide, comets were visualized using a light microscope attached to a digital camera with 510 excitation and 590 emission filters. The images were analyzed using the software Comet Assay IV (Perspective Instruments, Haverhill, UK). A total of 50 cells per slide and 2 slides per sample were scored for 'tail length' and 'tail moment'. Tail length is defined as the distance between the center of the comet head and the end of the tail. Tail moment is often considered a more significant indicator of DNA damage since they refer both to the distance of DNA migration and the amount of DNA in the tail (33). The higher the values of tail length and tail moment, as computed by the software, the higher the level of DNA damage.

Statistical analysis. The differences between comet assay mean values were analyzed for statistical significance $(\mathrm{p}<0.05)$ using Student's t-test. Statistical analysis of dose response was calculated using One-way Analysis of Variance (ANOVA).

\section{Results}

Effect of CSC on DNA strand breaks with time. Fig. 1 depicts the typical comet-like appearance of DNA strand breaks. ECT1/E6 E7 cells were treated with $8 \mu \mathrm{g} / \mathrm{ml} \mathrm{CSC} \mathrm{for} \mathrm{24,} \mathrm{48,}$ 72 , and $96 \mathrm{~h}$. The cell viability, as measured by trypan-blue dye exclusion, following a dose of $8 \mu \mathrm{g} / \mathrm{ml} \mathrm{CSC} \mathrm{(up} \mathrm{to} 72 \mathrm{~h}$ ) was $\geq 80 \%$ contributing to lower background damage and 


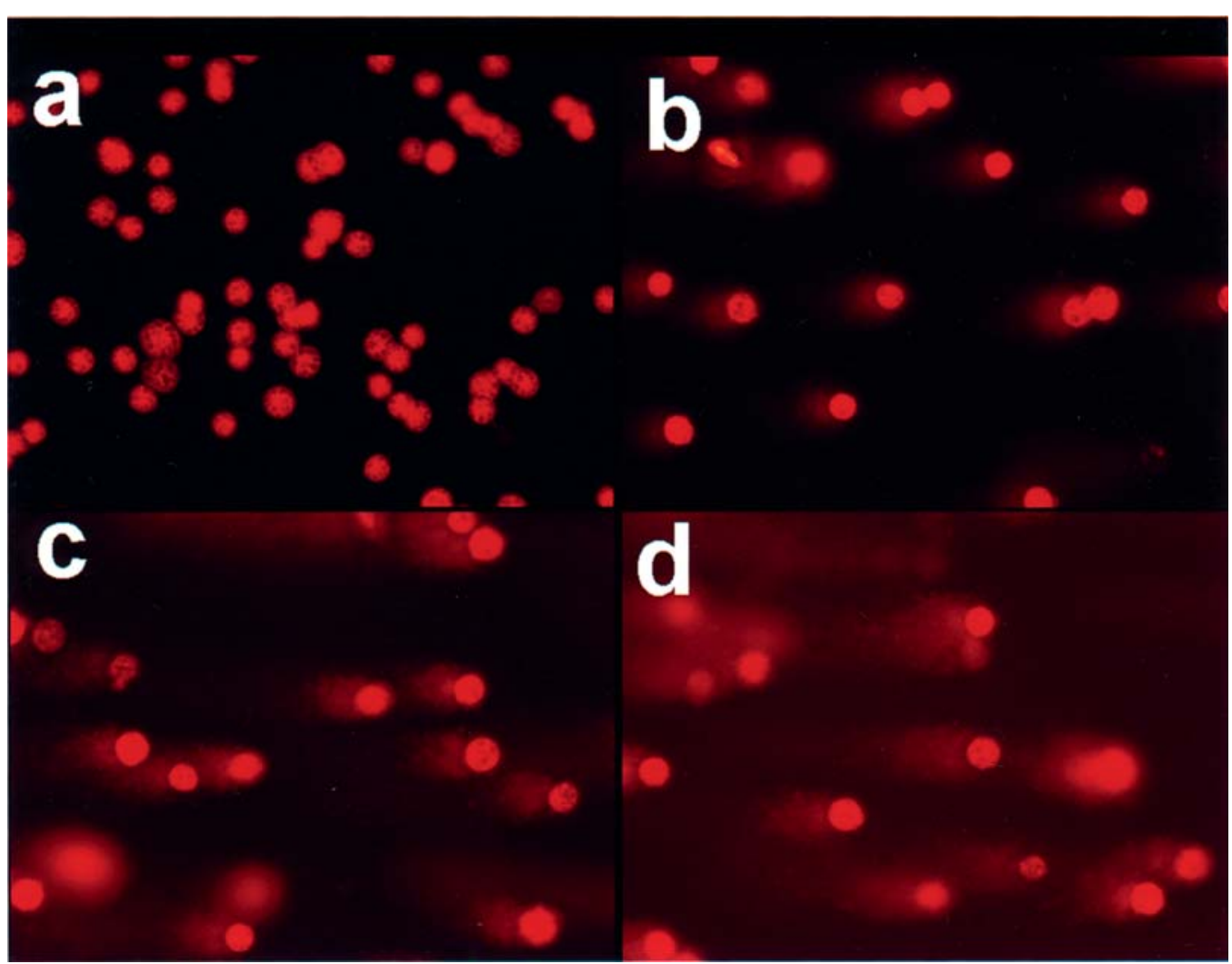

Figure 1. Representative comet assay images showing single-strand breaks in DNA of ECT1/E6 E7 cells treated with vehicle, $0.2 \%$ DMSO (a), and 4 (b), 8 (c) and 12 (d) $\mu \mathrm{g} / \mathrm{ml} \mathrm{CSC} \mathrm{for} 72 \mathrm{~h}$.
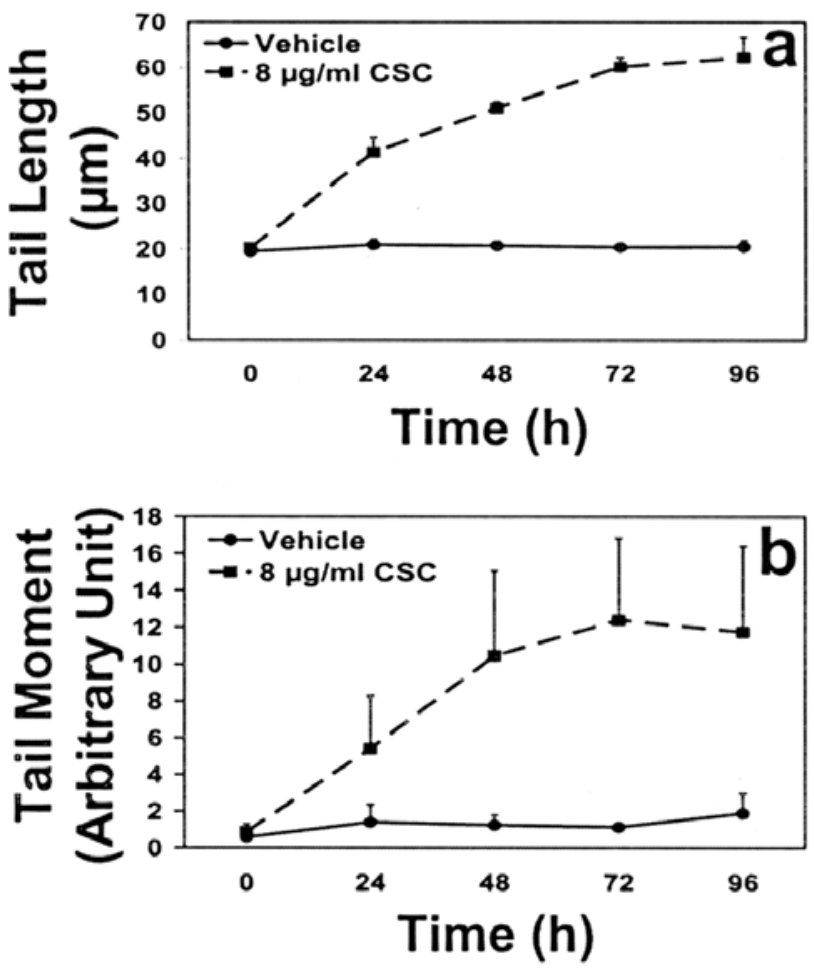

Figure 2. Time response of CSC on DNA single-strand formation as detected by (a) mean tail length (b) mean tail moment in alkaline comet assay following treatment of cells with $8 \mu \mathrm{g} / \mathrm{ml} \mathrm{CSC}$. Data represent mean $\pm \mathrm{SD}$ of 4 independent experiments. therefore considered ideal to study time response (data not shown). Since the rate of induction of single- and doublestrand breaks was almost the same (as described below) only single-strand breaks were measured. There was a timedependent increase (Fig. 2) in cells with single-strand breaks for both tail length, (2.9-fold; $\mathrm{p}<0.0001)$, and tail moment (14.4-fold; $\mathrm{p}=0.0109$ ), at $72 \mathrm{~h}$, compared to $0 \mathrm{~h}$. Beyond $72 \mathrm{~h}$, the tail length and tail moment plateaued. Taking this into account, the $72 \mathrm{~h}$ time-point was chosen to conduct the DNA damage and repair studies, since the maximum DNA strand breaks occurred at this treatment time.

Single- and double-strand breaks induced by different doses of CSC. Cells treated with CSC showed a clear dose-response with respect to the tail length and tail moment from 4-12 $\mu \mathrm{g} / \mathrm{ml}$ of CSC for both single- and double-strand breaks $(\mathrm{p}<0.0001)$ (Fig. 3). The rate of single- and double-strand break occurrence was essentially the same at all doses tested at $72 \mathrm{~h}$ of CSC treatment for tail length. The tail moment for doublestrand breaks was slightly lower as compared to single-strand breaks, although not statistically significant.

Doses of CSC higher than $12 \mu \mathrm{g} / \mathrm{ml}$ had a lethal effect on the cells (not shown). Treatment of the cells with $12 \mu \mathrm{g} / \mathrm{ml}$ CSC for $72 \mathrm{~h}$ generated the longest comet tail indicating the largest number of strand breaks, which represents an increased number of DNA fragments. Fig. 3c and d represent the number of cells with single- and double-strand breaks, respectively distributed at certain tail lengths following treatment with $0,4,8$, and $12 \mu \mathrm{g} / \mathrm{ml}$ concentrations of CSC; 

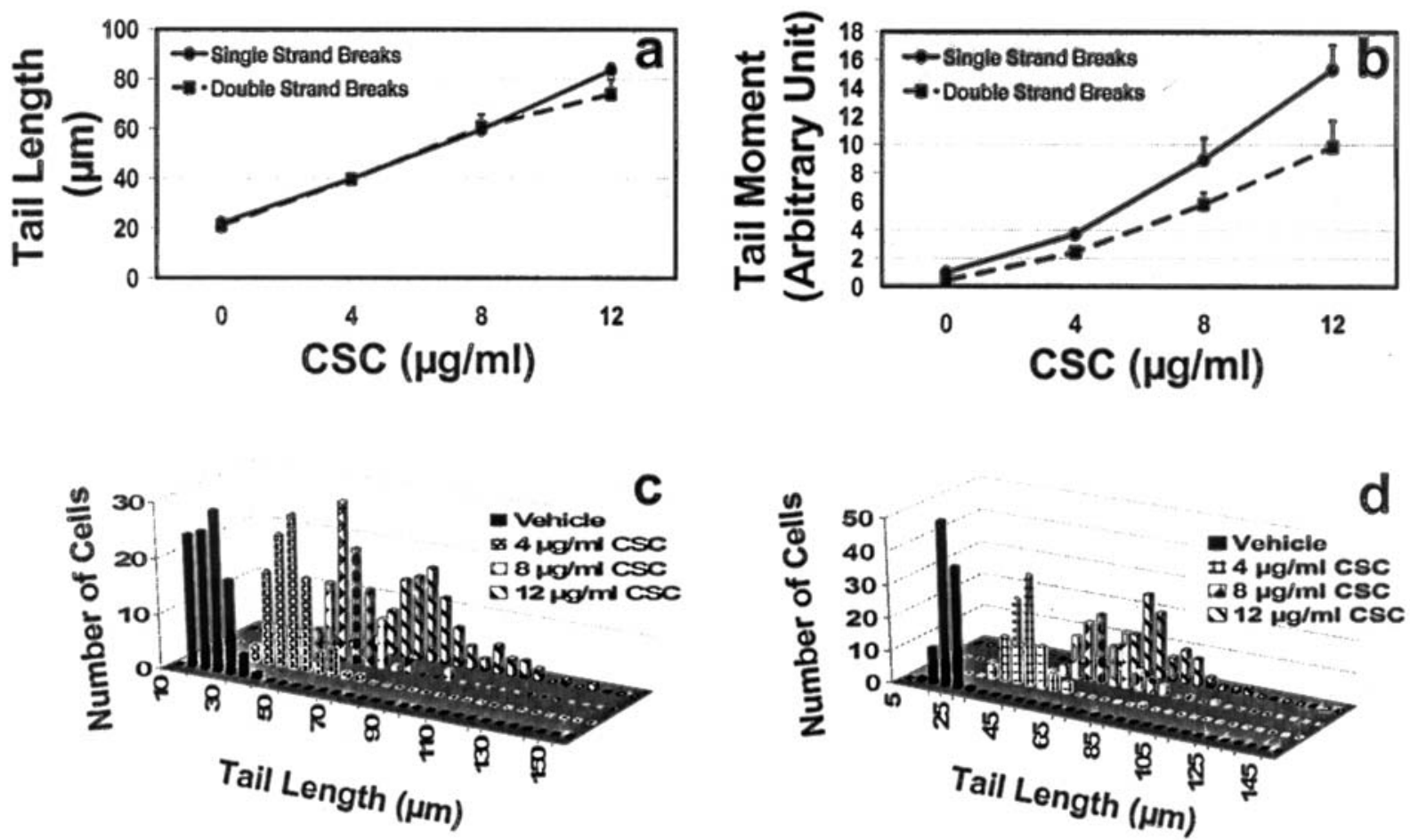

Figure 3. Dose response of CSC on single- and double-strand breaks: (a) mean tail length, (b) mean tail moment, and (c and d) distribution pattern of cells with single- and double strand breaks, respectively as measured by tail length after $72 \mathrm{~h}$, respectively. Data represent mean \pm SD of 4 independent experiments.
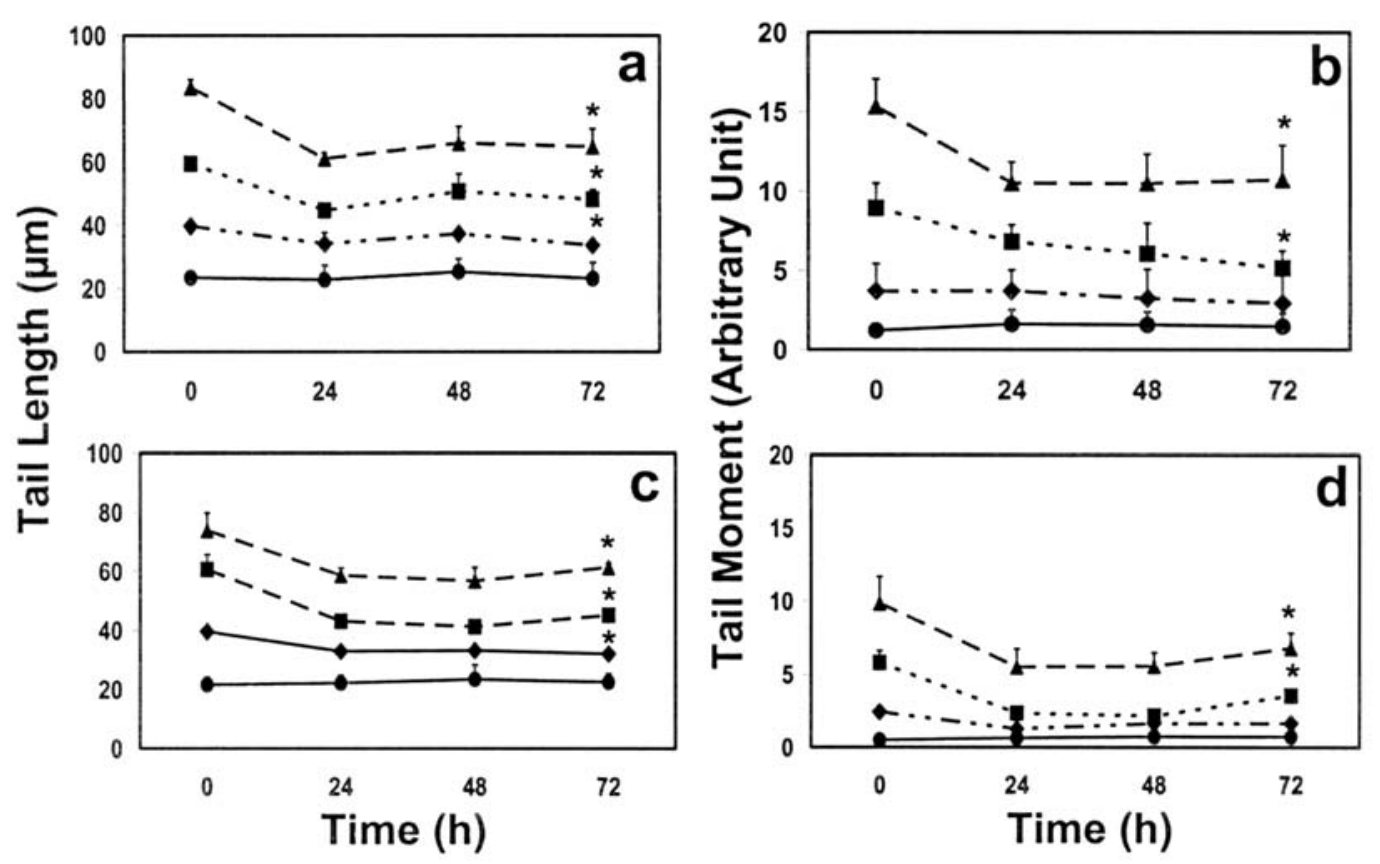

Figure 4. Repair of single- (a and b) and double-strand (c and d) DNA breaks. (a and c) tail length, (c and d) tail moment. Cells were treated for $72 \mathrm{~h}$ with 0 (circle), 4 (rhombus), 8 (square) and 12 (triangle) $\mu \mathrm{g} / \mathrm{ml} \mathrm{CSC}$, freed from residual CSC, and then incubated for up to $72 \mathrm{~h}$ for DNA repair to occur. Data represent mean \pm SD of 4 independent experiments. ${ }^{*} \mathrm{p}<0.05$.

increase in concentration of CSC indicates a greater number of strand breaks.

DNA repair studies. A significant amount of both single- and double-strand breaks were repaired in the first $24 \mathrm{~h}$ following treatment with 4, 8 and $12 \mu \mathrm{g} / \mathrm{ml} \mathrm{CSC} \mathrm{for} 72 \mathrm{~h}$ (Fig. 4): At the highest concentration of CSC, tail length and tail moment of single strand breaks were repaired by 27 and $32 \%$, respectively after $24 \mathrm{~h}$; tail length and tail moment of double-strand breaks were repaired by $21 \%$ and $44 \%$, respectively at the 

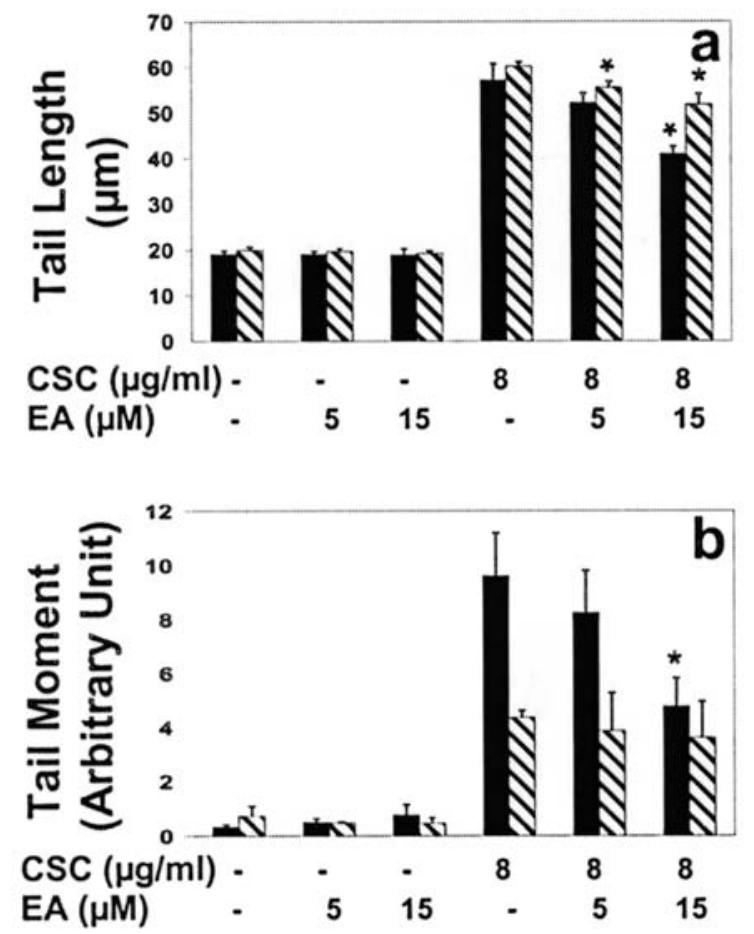

Figure 5. Effect of ellagic acid on cigarette smoke condensate-induced single- and double-strand DNA breaks as measured by tail length (a) and tail moment (b). The cells were pretreated with 5 or $15 \mu \mathrm{M}$ ellagic acid for $20 \mathrm{~h}$, followed by co-treatment with $8 \mu \mathrm{g} / \mathrm{ml}$ cigarette smoke condensate for $72 \mathrm{~h}$. Data represent mean \pm SD of 3 independent experiments. ${ }^{*} \mathrm{p}<0.05$, black bar, single-strand breaks; diagonally lined bar, double-strand breaks.

same concentration. No further removal of either single- or double-strand breaks was observed. DNA repair at the two lower concentrations of CSC followed essentially the same kinetics (Fig. 4).

Ellagic acid and oxidative damage. Cells treated with $5 \mu \mathrm{M}$ EA showed a reduction in the level of single-strand breaks measured both as tail length (9\%) and tail moment (15\%) although not statistically significant (Fig. 5). At a higher dose $(15 \mu \mathrm{M})$ of EA, however, single-strand breaks were diminished significantly $-28 \%(\mathrm{p}=0.0019)$ reduction in tail length and $50 \%$ $(\mathrm{p}=0.0115)$ reduction in tail moment (Fig. 5). The tail length of double-strand breaks were also significantly reduced by nearly $8 \%(\mathrm{p}=0.0076)$ and $14 \%(\mathrm{p}=0.0042)$ with 5 and $15 \mu \mathrm{M}$ EA treatment, respectively. The tail moment, however, was unaltered.

\section{Discussion}

It has been reported that cigarette smoke has a late stage synergistic effect in cervical carcinogenesis initiated by HPV infection $(6,26)$. Nonetheless, the mechanism of smoking on the neoplastic progression of cervical cells remains inconclusive. The aim of this study was to investigate CSCinduced DNA damage and subsequent repair in HPVimmortalized cervical cells. In order to further understand the interplay of smoking and cervical carcinogenesis, we employed the comet assay to measure single- and doublestrand DNA damage and subsequent repair.
The principle of the comet assay is based on alterations found in DNA such as strand breaks resulting in the extension of DNA loops from lysed and salt-extracted nuclei, which, in turn, form a comet-like tail after either alkaline electrophoresis, indicating SSBs, or neutral electrophoresis, indicating DSBs $(27,34)$. In previous studies in which the effects of cigarette smoke condensate/cigarette smoke on DNA strand breaks were investigated by the comet assay, only DNA single-strand breaks were detected $(18,35,36)$. The interaction of CSC on DNA strand breaks in HPV-transformed cervical cells has not been reported previously.

In the present study, we showed that CSC in HPV-infected cervical cells is able to induce similar levels of DNA singleand double-strand breaks in a dose- and time-dependent manner. Based on experimental and epidemiological studies, cigarette smoke accounts for a significant risk factor in developing cancer of various organs (37), including those of the cervix (38-40). Numerous genotoxic effects of CSC, including DNA strand breaks, have also been demonstrated in other human culture cells $(17,18,41-43)$. However, this finding has not been demonstrated previously in HPVinfected cervical cells. We speculated that DNA integrity is compromised when cigarette smoke acts in conjunction with HPV in the cells. Nonetheless, the effects of CSC as a heterogeneous component on the extent of DNA damage in the cells are complex. Moreover, since CSC consists of many tumor promoters such as catechol and hydroquinone (44) as well as inhibitors such as unsaturated aldehydes (45), it is difficult to pinpoint the specific carcinogens, present in CSC, which are responsible for DNA strand breaks. Our finding supports epidemiological data suggesting that cigarette smoke acts in synergy with HPV in cervical carcinogenesis.

In the current study, single- and double-strand breaks were two types of DNA damage investigated. SSBs are considered an indicator of early damage (24). Also, SSBs are intermediate processing products of DNA damage, which, if left unrepaired, may develop into mutagenic and lethal double-strand breaks (46). Conversely, DSBs are considered more biologically relevant lesions (24). DSBs are a more disruptive form of strand break since they can either lead to cell death or loss of genetic information, if left unrepaired, or they may cause neoplastic progression if the repair process is compromised $(25,47)$.

Since the DNA repair capability is an important factor believed to influence the outcome of DNA damage, we examined the repair efficiency of HPV-transformed cervical cells in combating CSC-induced strand breaks. From our results, it appears that cells attain DNA single- and doublestrand breaks at all concentrations of CSC tested and that maximum repair of DNA single- and double-strand breaks occurred during the first $24 \mathrm{~h}$ and plateaued afterwards. The present study also suggests that the repair of CSC-induced DNA damage occurred only during the first $24 \mathrm{~h}$ and no further repair was observed. This trend was observed for both single- and double-strand breaks. This observation is in agreement with radiation-induced SSBs in leukocytes (48) and SSBs and DSBs in mouse embryo fibroblasts (24). In the latter study, in contrast to the current findings, SSBs were completely repaired after $24 \mathrm{~h}$ post radiation, whereas DSBs were not (24). Additionally, based on our repair studies, 
the ability of the cells to repair CSC-induced DNA strand breaks reached a plateau after first $24 \mathrm{~h}$ regardless of CSC concentration. Therefore, it can be concluded that the cellular repair response depends on the cell type, the nature of strand breaks, the type of carcinogen as well as the DNA repair capacity of the cells. It is possible that at CSC concentrations lower than the ones tested in this study, ECT1/E6 E7 cells endure less strand breaks, which could be repaired efficiently. However, if DNA repair capacity of the cells is compromised due to the HPV infection, the CSC-induced breaks may be poorly repaired which may lead to the accumulation of mutations.

It has been reported that HPV infection compromises the DNA repair system such as alteration in gene amplification, expression of DNA repair enzymes (49) and microsatellite instability (50). It is conceivable that expression and function of genes responsible for the repair of strand breaks might be responsible for the differences in the rate of the repair of CSC-induced damage. The repair of HPV16-immortalized ectocervical epithelial cells to PAHs, such as benzo[ $a$ ]pyrene (BP), present in cigarette smoke, was found to be impaired due to reduced p53 in those cells (51). Moreover, BP has been shown to manipulate multiple HPV life cycle functions, which, in turn, may influence cervical cancer progression (52).

Cigarette smoke may also contribute to the deficiency of DNA repair in rejoining of the strand breaks. In this study, both single- and double-strand DNA breaks were highly persistent. We found that CSC-induced DNA damage was much more persistent than ionizing radiation-induced damage which was completely repaired within $2 \mathrm{~h}$ (18). This finding might be due to genotoxic compounds present in CSC which have been shown to slow DNA repair kinetics. It has been reported that acrolein, also a constituent of cigarette smoke, was found to inhibit the repair of DNA damage. Therefore, it is reasonable to conclude that impaired DNA repair by CSC may have a role in fixation of DNA damage in cervical cells, leading to accumulation of mutations and cancer development. In theory, SSBs should be repaired by using the undamaged strand as a template, whereas DSBs can be repaired by two repair pathways, namely homologous recombination or nonhomologous end-joining $(24,53)$. Indeed, further investigation is required to identify the repair pathway that may have been affected in the CSC-treated cervical cells. To the best of our knowledge, this is the first demonstration of the kinetics of CSC-induced DNA strand breaks and of global repair of the damage in human cervical cells.

In order to investigate if free radicals are the source of oxidative DNA damage, we examined the effect of an antioxidant, EA, in mitigating CSC-induced DNA damage. In our investigation, EA showed significant, dose-dependent reduction in CSC-induced single- and double-strand breaks. Cigarette smoke contains a broad range of carcinogens, including redox-active catechols, which may lead to the induction of oxidative stress and eventually contribute to increased genomic instability and cancer development $(54,55)$, including cervical cancer (56). It has been reported that the highly reactive hydroxyl radicals generated from cigarette smoke contribute in the formation of DNA single-strand breaks in vitro $(14,17)$. EA is a phenolic lactone that exerts its anticarcinogenic and antimutagenic activities through several mechanisms, including scavenging reactive oxygen species $(30,57,58)$. This observation is in agreement with previous studies investigating the antioxidant activities of EA on DNA strand breaks $(59,60)$. Our data suggest that CSC-induced DNA strand breaks may, in part, originate from free radicals.

Interestingly, we found that EA did not significantly reduce basal levels of both single- and double-strand breaks. Based upon our findings, we speculate that there may be two possible explanations for the lack of attenuation of basal levels of DNA strand breaks. First, cigarette smoke contains more than 5,000 chemicals with diverse interactions (60), which may influence the effectiveness of EA to act as an antioxidant. Second, in our laboratory, it has been reported that EA was a potent inhibitor of dibenzo[ $[a, l]$ pyrene-DNA adducts in a microsome-mediated test system by $\geq 75 \%$ (61). However, using a cellular system, EA inhibited the same adducts by only $16 \%$ (62). Thus, it seems reasonable to speculate that, in the present study, limited EA uptake by the cells may be a possibility for lower inhibition of CSC-induced oxidative stress in the presence of the antioxidant. Despite the fact that EA has antioxidant activity and is a direct radical scavenger (30), the mechanisms by which EA can further reduce DNA strand breaks induced by CSC in the cervical cells await further study. There are ongoing experiments in this laboratory to further investigate whether reactive oxygen species are a source of CSC-induced DNA damage in the $\mathrm{HPV}$-infected cervical cells.

In conclusion, our study highlights the inability of HPVtransfected cells to completely repair CSC-induced DNA damage. Furthermore, we demonstrated that the oxidative stress may be the source of DNA damage caused by CSC. The significance of our study stems from the fact that DNA lesions and/or persistent DNA strand breaks, caused by the inability of the cells to remove the damage, may result in accumulation of mutations leading to cancer (63). These findings support the previously found epidemiological association between HPV infection, cigarette smoke exposure and cervical cancer development $(64,65)$. Our result suggests that cigarette smokers infected with HPV may be at a higher risk for cervical cancer.

\section{Acknowledgments}

The authors thank Dr Raina Fichorova of Brigham and Women's Hospital, Harvard Medical School for providing HPV16-transformed cells (ECT1/E6 E7), Dr Wendy Spencer for assisting in the preparation of this manuscript, and Dr Alfred B. Jenson for helpful discussion. This work was, in part, supported from Agnes Brown Duggan Endowment, and a graduate fellowship from the University of Louisville School of Medicine (to A.M.).

\section{References}

1. Zur Hausen H, de Villiers EM and Gissmann L: Papillomavirus infections and human genital cancer. Gynecol Oncol 12: S124-S128, 1981.

2. Lorincz AT, Reid R, Jenson AB, Greenberg MD, Lancaster W and Kurman RJ: Human papillomavirus infection of the cervix: relative risk associations of 15 common anogenital types. Obstet Gynecol 79: 328-337, 1992. 
3. Walboomers JM, Jacobs MV, Manos MM, et al: Human papillomavirus is a necessary cause of invasive cervical cancer worldwide. J Pathol 189: 12-19, 1999.

4. Schiffman M and Castle PE: Human papillomavirus: epidemiology and public health. Arch Pathol Lab Med 127: 930-934, 2003.

5. Duensing S and Munger K: Centrosomes, genomic instability, and cervical carcinogenesis. Crit Rev Eukaryot Gene Expr 13: 9-23, 2003.

6. Castellsague X and Munoz N: Chapter 3: Cofactors in human papillomavirus carcinogenesis - role of parity, oral contraceptives, and tobacco smoking. J Natl Cancer Inst Monogr 20-28, 2003.

7. American Cancer Society: Cervical Cancer. What are the risk factors for cervical cancer? Atlanta, GA, 2008.

8. De Marini DM: Genotoxicity of tobacco smoke and tobacco smoke condensate: a review. Mutat Res 567: 447-474, 2004.

9. Hoffmann D, Hoffmann I and El-Bayoumy K: The less harmful cigarette: a controversial issue. a tribute to Ernst L. Wynder. Chem Res Toxicol 14: 767-790, 2001.

10. Hecht SS: Tobacco carcinogens, their biomarkers and tobaccoinduced cancer. Nat Rev 3: 733-744, 2003.

11. Thun MJ, Henley SJ and Calle EE: Tobacco use and cancer: an epidemiologic perspective for geneticists. Oncogene 21: 7307-7325, 2002.

12. Hecht SS: Tobacco smoke carcinogens and lung cancer. J Natl Cancer Inst 91: 1194-1210, 1999.

13. Leanderson P and Tagesson C: Cigarette smoke-induced DNAdamage: role of hydroquinone and catechol in the formation of the oxidative DNA-adduct, 8-hydroxydeoxyguanosine. Chem Biol Interact 75: 71-81, 1990.

14. Leanderson P and Tagesson C: Cigarette smoke-induced DNA damage in cultured human lung cells: role of hydroxyl radicals and endonuclease activation. Chem Biol Interact 81: 197-208, 1992.

15. Paz-Elizur T, Ben-Yosef R, Elinger D, et al: Reduced repair of the oxidative 8-oxoguanine DNA damage and risk of head and neck cancer. Cancer Res 66: 11683-11689, 2006.

16. Asami S, Hirano T, Yamaguchi R, Tomioka Y, Itoh $\mathrm{H}$ and Kasai $\mathrm{H}$ : Increase of a type of oxidative DNA damage, 8hydroxyguanine, and its repair activity in human leukocytes by cigarette smoking. Cancer Res 56: 2546-2549, 1996.

17. Nakayama T, Kaneko M, Kodama $M$ and Nagata C: Cigarette smoke induces DNA single-strand breaks in human cells. Nature 314: 462-464, 1985

18. Yang Q, Hergenhahn M, Weninger A and Bartsch H: Cigarette smoke induces direct DNA damage in the human B-lymphoid cell line Raji. Carcinogenesis 20: 1769-1775, 1999.

19. Kato T, Nagasawa H, Warner C, Okayasu R and Bedford JS: Cytotoxicity of cigarette smoke condensate is not due to DNA double strand breaks: Comparative studies using radiosensitive mutant and wild-type CHO cells. Int J Radiat Biol 83: 583-591, 2007.

20. Albino AP, Huang X, Jorgensen ED, Gietl D, Traganos F and Darzynkiewicz Z: Induction of DNA double-strand breaks in A549 and normal human pulmonary epithelial cells by cigarette smoke is mediated by free radicals. Int J Oncol 28: 1491-1505, 2006.

21. Sancar A, Lindsey-Boltz LA, Unsal-Kacmaz K and Linn S: Molecular mechanisms of mammalian DNA repair and the DNA damage checkpoints. Annu Rev Biochem 73: 39-85, 2004

22. Kassie F, Parzefall W and Knasmuller S: Single cell gel electrophoresis assay: a new technique for human biomonitoring studies. Mutat Res 463: 13-31, 2000.

23. Rojas E, Lopez MC and Valverde M: Single cell gel electrophoresis assay: methodology and applications. J Chromatogr B Biomed Sci Appl 722: 225-254, 1999.

24. Calini V, Urani C and Camatini M: Comet assay evaluation of DNA single- and double-strand breaks induction and repair in C3H10T1/2 cells. Cell Biol Toxicol 18: 369-379, 2002.

25. Chu G: Double strand break repair. J Biol Chem 272: 24097-24100, 1997.

26. Zur Hausen H: Human genital cancer: synergism between two virus infections or synergism between a virus infection and initiating events? Lancet 2: 1370-1372, 1982.

27. Singh NP, McCoy MT, Tice RR and Schneider EL: A simple technique for quantitation of low levels of DNA damage in individual cells. Exp Cell Res 175: 184-191, 1988.

28. Singh NP, Muller CH and Berger RE: Effects of age on DNA double-strand breaks and apoptosis in human sperm. Fertil Steril 80: 1420-1430, 2003.
29. Singh NP: Microgels for estimation of DNA strand breaks, DNA protein crosslinks and apoptosis. Mutat Res 455: 111-127, 2000.

30. Festa F, Aglitti T, Duranti G, Ricordy R, Perticone P and Cozzi R: Strong antioxidant activity of ellagic acid in mammalian cells in vitro revealed by the comet assay. Anticancer Res 21: 3903-3908, 2001

31. Wu LT, Chu CC, Chung JG, Chen CH, Hsu LS, Liu JK and Chen SC: Effects of tannic acid and its related compounds on food mutagens or hydrogen peroxide-induced DNA strands breaks in human lymphocytes. Mutat Res 556: 75-82, 2004.

32. Pillsbury $\mathrm{HC}$ and Bright CC: Comparison of aliquot and complete sample procedure for the determination of nicotine in cigarette smoke. J Assoc Anal Chem 55: 636-638, 1972.

33. Olive PL, Banath JP and Durand RE: Heterogeneity in radiation-induced DNA damage and repair in tumor and normal cells measured using the 'comet' assay. Radiat Res 122: 86-94, 1990.

34. Collins AR: The comet assay. Principles, applications, and limitations. Methods Mol Biol 203: 163-177, 2002.

35. Speit G, Witton-Davies T, Heepchantree W, Trenz K and Hoffmann $\mathrm{H}$ : Investigations on the effect of cigarette smoking in the comet assay. Mutat Res 542: 33-42, 2003.

36. Sinko I, Morocz M, Zadori J, Kokavszky K and Rasko I: Effect of cigarette smoking on DNA damage of human cumulus cells analyzed by comet assay. Reprod Toxicol 20: 65-71, 2005.

37. Parkin DM, Pisani P, Lopez AD and Masuyer E: At least one in seven cases of cancer is caused by smoking. Global estimates for 1985. Int J Cancer 59: 494-504, 1994.

38. Zur Hausen H: Papillomaviruses causing cancer: evasion from host-cell control in early events in carcinogenesis. J Natl Cancer Inst 92: 690-698, 2000

39. Coker AL, Rosenberg AJ, McCann MF and Hulka BS: Active and passive cigarette smoke exposure and cervical intraepithelial neoplasia. Cancer Epidemiol Biomarkers Prev 1: 349-356, 1992.

40. Castle PE, Wacholder S, Lorincz AT, et al: A prospective study of high-grade cervical neoplasia risk among human papillomavirus-infected women. J Natl Cancer Inst 94: 1406-1414, 2002.

41. Fielding S, Short C, Davies K, Wald N, Bridges BA and Waters R: Studies on the ability of smoke from different types of cigarettes to induce DNA single-strand breaks in cultured human cells. Mutat Res 214: 147-151, 1989.

42. Yoshie Y and Ohshima H: Synergistic induction of DNA strand breakage by cigarette tar and nitric oxide. Carcinogenesis 18: 1359-1363, 1997.

43. Willey JC, Grafstrom RC, Moser CE, Ozanne C, Sundquvist K and Harris CC: Biochemical and morphological effects of cigarette smoke condensate and its fractions on normal human bronchial epithelial cells in vitro. Cancer Res 47: 2045-2049, 1987.

44. Gopalakrishna R, Chen ZH and Gundimeda U: Tobacco smoke tumor promoters, catechol and hydroquinone, induce oxidative regulation of protein kinase $\mathrm{C}$ and influence invasion and metastasis of lung carcinoma cells. Proc Natl Acad Sci USA 91: 12233-12237, 1994.

45. Lambert C, Li J, Jonscher K, Yang TC, Reigan P, Quintana M, Harvey $\mathrm{J}$ and Freed BM: Acrolein inhibits cytokine gene expression by alkylating cysteine and arginine residues in the NF-kappaB1 DNA binding domain. J Biol Chem 282: 19666-19675, 2007

46. Caldecott KW: Mammalian single-strand break repair: mechanisms and links with chromatin. DNA Repair (Amst) 6: 443-453, 2007.

47. Nocentini S: Rejoining kinetics of DNA single- and doublestrand breaks in normal and DNA ligase-deficient cells after exposure to ultraviolet $\mathrm{C}$ and gamma radiation: an evaluation of ligating activities involved in different DNA repair processes. Radiat Res 151: 423-432, 1999.

48. Pincheira J, Carrera P, Marcelain K and De La Torre C: Hepatocytes, rather than leukocytes reverse DNA damage in vivo induced by whole body gamma-irradiation of mice, as shown by the alkaline comet assay. Biol Res 41: 217-225, 2008.

49. Sohn TJ, Kim NK, An HJ, et al: Gene amplification and expression of the DNA repair enzyme, N-methylpurine-DNA glycosylase (MPG) in HPV-infected cervical neoplasias. Anticancer Res 21: 2405-2411, 2001

50. Clarke B, Gordon M, Moodley M, Naidoo R and Chetty R: Microsatellite analysis of early stage (Ia-IIb) uterine cervical squamous carcinoma. Int J Surg Pathol 11: 253-260, 2003. 
51. Sizemore N, Mukhtar H, Couch LH, Howard PC and Rorke EA: Differential response of normal and HPV immortalized ectocervical epithelial cells to B[a]P. Carcinogenesis 16: 2413-2418, 1995.

52. Alam S, Conway MJ, Chen HS and Meyers C: The cigarette smoke carcinogen benzo[a]pyrene enhances human papillomavirus synthesis. J Virol 82: 1053-1058, 2008.

53. Moustacchi E: DNA damage and repair: consequences on doseresponses. Mutat Res 464: 35-40, 2000.

54. Godschalk R, Nair J, van FJ, et al: Comparison of multiple DNA adduct types in tumor adjacent human lung tissue: effect of cigarette smoking. Carcinogenesis 23: 2081-2086, 2002.

55. Huang YL, Chuang CY, Sung FC and Chen CY: Thioredoxin overexpression modulates remodeling factors in stress responses to cigarette smoke. J Toxicol Environ Health A 71: 1490-1498, 2008.

56. Goncalves TL, Erthal F, Corte CL, Muller LG, Piovezan CM, Nogueira CW and Rocha JB: Involvement of oxidative stress in the pre-malignant and malignant states of cervical cancer in women. Clin Biochem 38: 1071-1075, 2005.

57. Das M, Bickers DR and Mukhtar H: Effect of ellagic acid on hepatic and pulmonary xenobiotic metabolism in mice: studies on the mechanism of its anticarcinogenic action. Carcinogenesis 6: 1409-1413, 1985.

58. Sudheer AR, Muthukumaran S, Devipriya N and Menon VP: Ellagic acid, a natural polyphenol protects rat peripheral blood lymphocytes against nicotine-induced cellular and DNA damage in vitro: with the comparison of $\mathrm{N}$-acetylcysteine. Toxicology 230: 11-21, 2007.
59. Chakraborty S, Roy M and Bhattacharya RK: Prevention and repair of DNA damage by selected phytochemicals as measured by single cell gel electrophoresis. J Environ Pathol Toxicol Oncol 23: 215-226, 2004.

60. Suda S, Matsusaka N, Ueno S, Susa N and. Sasaki YF: The influence of antioxidants on cigarette smoke-induced DNA single-strand breaks in mouse organs: a preliminary study with the alkaline single cell gel electrophoresis assay. Toxicol Sci 54: 104-109, 2000.

61. Smith WA, Arif JM and Gupta RC: Effect of cancer chemopreventive agents on microsome-mediated DNA adduction of the breast carcinogen dibenzo[a,l]pyrene. Mutat Res 412: 307-314, 1998.

62. Smith WA, Freeman JW and Gupta RC: Effect of chemopreventive agents on DNA adduction induced by the potent mammary carcinogen dibenzo[a,1]pyrene in the human breast cells MCF-7. Mutat Res 480-481: 97-108, 2001.

63. Bohr VA: DNA repair fine structure and its relations to genomic instability. Carcinogenesis 16: 2885-2892, 1995.

64. Haverkos HW: Multifactorial etiology of cervical cancer: a hypothesis. MedGenMed 7: 57, 2005.

65. Haverkos HW, Soon G, Steckley SL and Pickworth W: Cigarette smoking and cervical cancer: Part I: a meta-analysis. Biomed Pharmacother 57: 67-77, 2003. 